\title{
Cree Language
}

National Cancer Institute

\section{Source}

National Cancer Institute. Cree Language. NCI Thesaurus. Code C153889.

A dialect continuum of Algonquian languages native to areas of Canada and the United States. 